\title{
Vulvar Non-Keratinizing Squamous Cell
} Carcinoma

National Cancer Institute

\section{Source}

National Cancer Institute. Vulvar Non-Keratinizing Squamous Cell Carcinoma. NCI Thesaurus. Code C40285.

A squamous cell carcinoma that arises from the vulva and is characterized by the absence of keratin pearls. 